\title{
PENGARUH PARTISIPASI PENYUSUNAN KEY PERFORMANCE INDICATOR (KPI) TERHADAP KOMITMEN PENCAPAIAN SASARAN KERJA KARYAWAN DI PT. XYZ, YOGYAKARTA
}

\author{
Rislisa $^{1}$, Fathul Himam ${ }^{2}$ \\ $\left.{ }^{1}\right)$ Program Magister Psikologi Profesi, Fakultas Psikologi, Universitas Mercu Buana, \\ Kampus 2, Jl. Jembatan Merah 84 C, Yogyakarta \\ $\left.{ }^{2}\right)$ Fakultas Psikologi, Universitas Gadjah Mada, Yogyakarta \\ Jl. Humaniora no.1 Bulaksumur Yogyakarta \\ icha_candyd@yahoo.com
}

\begin{abstract}
Providing information about the reasons and rationale of why a set of purpose is considered important and the participation in setting the work purpose serve as important factors to improve employees' work commitment to the goal. This study was aimed to determine the effect of participation in setting the key performance indicator (KPI) to increase the commitment for achievement of work objectives in PT. XYZ. There were 36 subjects involved in this research, which consisted of 18 individuals assigned randomly as experimental group and 18 individuals as control group. The design of this experimental research was pretest-posttest control group design. KPI preparation participation treatment was given to the experimental groups and the control groups did not receive treatment. ANOVA analysis was use to analyze the data. This research indicated, that there was no significant effect of participation in setting Key Performance Indicator (KPI) on work goals commitment. (F $=.425 ; \mathrm{p}>.05)$. On the other hand, this research found a tendency that commitment could increase knowledge and subjects' understanding in how to achieve work goals.
\end{abstract}

Keywords: employee participation, key performance indicator, work goals commitment

\begin{abstract}
Abstrak
Memberikan informasi tentang alasan mengapa suatu tujuan kerja itu penting serta partisipasi karyawan saat penentuan tujuan merupakan faktor penting untuk meningkatkan komitmen karyawan pada sasaran kerjanya. Penelitian ini bertujuan untuk mengetahui pengaruh partisipasi penyusunan key performance indicator (KPI) terhadap komitmen pencapaian sasaran kerja karyawan di PT. XYZ. Subjek dalam penelitian ini berjumlah 36 subjek, yang terdiri atas 18 kelompok eksperimen dan 18 kelompok kontrol. Pengambilan subjek penelitian dilakukan dengan teknik random assignment. Penelitian ini merupakan penelitian eksperimen dengan desain penelitian pretest-posttest control group design. Partisipasi karyawan dalam penyusunan KPI merupakan perlakuan yang diberikan kepada kelompok eksperimen sedangkan kelompok kontrol tidak mendapatkan perlakukan. ANOVA menunjukkan hasil yang tidak signifikan pada pengaruh partisipasi penyusunan key performance indicator (KPI) terhadap komitmen pencapaian sasaran kerja tidak signifikan $(F=0,425 ; p>0,05)$. Disisi lain, penelitian ini menemukan bahwa partisipasi lebih cenderung meningkatkan pengetahuan dan pemahaman subjek mengenai pencapaian sasaran kerja. Disarankan pada penelitian selanjutnya untuk melakukan pengontrolan pada faktor-faktor yang dapat mempengaruhi validitas internal.
\end{abstract}

Kata kunci: partisipasi karyawan; key performance indicator (KPI); komitmen pencapaian sasaran kerja

\section{PENDAHULUAN}

Organisasi dibentuk sebagai wadah bagi sekelompok individu dalam mencapai tujuan-tujuan tertentu. Efektif tidaknya organisasi tergantung kepada sinergi atau kerjasama individu dan kelompok dalam organisasi untuk mencapai tujuan atau sasaran bersama (Hidayat, 2013). Untuk dapat bekerjasama dan berprestasi dengan baik, seorang karyawan harus mempunyai komitmen yang tinggi pada organisasinya 
(Tranggono \& Kartika, 2008), disamping itu keberhasilan dan kinerja seseorang dalam suatu bidang pekerjaan banyak ditentukan oleh tingkat kompetensi, profesionalisme juga komitmen terhadap bidang yang ditekuninya (Yudhaningsih, 2011).

Komitmen yang rendah yang dimiliki oleh karyawan pada perusahaan merupakan kerugian bagi perusahaan itu sendiri, terutama bila terjadi pada karyawan yang telah dididik dan berpengalaman. Kerugian itu akan menyebabkan beban yang berat bagi perusahaan sebagai akibat tidak terpenuhinya harapan karyawan dalam bekerja, sehingga perlu dilakukan usaha penanggulangan dan pencegahan gejala kerja negatif dengan cara menumbuhkan dan meningkatkan komitmen karyawan (Oktorita, Rosyid \& Lestari, 2001). Teori penetapan tujuan (goal-setting) dimunculkan dan disebarkan oleh Edwin Locke pada akhir tahun 1960an. Locke membuat artikel yang berjudul "Toward a theory of task motivation and incentives" pada tahun 1968. Artikel ini menjelaskan bahwa bekerja menuju tujuan merupakan sumber motivasi utama untuk mencapai tujuan yang sebenarnya. Hal ini menjadikan individu cenderung untuk lebih gigih dalam meningkatkan kinerja tugas daripada ketika ia tidak memiliki penetapan tujuan yang jelas (Locke, Shaw, Saari, \& Latham 1981).

Berdasarakan penelitian yang sudah dilakukan oleh Locke pada tahun 1960an tentang penetapan tujuan, dilakukan penelitian lanjutan oleh Hollenbeck, Williams, dan Klein (1989) yang menghasilkan sembilan aitem untuk melihat komitmen tujuan. Dari sembilan aitem tersebut, terdapat lima aitem yang memiliki skor yang tinggi yang dapat menggambarkan komitmen tujuan yang tinggi. Selanjutnya dilakukan kembali penelitian oleh Klein, Wesson Hollenbeck, dan Alge (1999); Klein, dkk (2001); serta Hidayat (2010) untuk melihat komitmen tujuan dengan menggunakan aitem yang berasal dari penelitian yang dilakukan oleh Hollenbeck, dkk (1989). Selanjutnya Sholihin, Pike, Mangena, dan Li (2011); dan Lau (2012) melakukan penelitian lanjutan dengan menggunakan tiga aitem dari Hollenbeck dkk, untuk mengukur komitmen tujuan, yaitu (1) saya berpikir bahwa sasaran kinerja itu dapat diperjuangkan, (2) saya bersedia untuk melakukan banyak usaha dalam mencapai sasaran kinerja, dan (3) saya sangat berkomitmen untuk mencapai tujuan kinerja. Penelitian yang telah dilakukan untuk melihat komitmen tujuan yang masih bersifat umum dalam melihat tujuan sehingga pada penelitian ini lebih dispesifikkan lagi menjadi komitmen pencapain sasaran kerja, untuk dapat melihat bagaimana komitmen karyawan untuk mencapai sasaran kerjanya.

Armstrong (2003) mengatakan bahwa sasaran adalah sesuatu yang harus dicapai, baik sebagai tujuan (target), rencana atau proyek yang harus diimplementasikan atau diselesaikan, standar kinerja yang harus dicapai atau dipertahankan, sasaran pengembangan pribadi atau nilai-nilai yang harus dipertahankan. Moorhead dan Griffin (2013) juga menambahkan bahwa penetapan sasaran adalah metode yang sangat berguna untuk meningkatkan kinerja karyawan.

Pada PT. XYZ penilaian kinerja karyawan yang diharapkan dapat menilai kinerja karyawan belum mampu untuk melihat pencapaian sasaran kerja karyawan karena penilaian yang digunakan masih berorientasi pada penilaian kepribadian (personality) dan perilaku (behavior) terfokus pada pembentukan karakter individu dengan menggunakan kriteria perilaku dan belum terfokus pada kinerja, peningkatan hasil, produktivitas (end 
result) dan pengembangan pemanfaatan potensi. Penilaian kinerja yang sudah digunakan kurang dapat melihat pencapaian kinerja dan pelaksanaan pekerjaan yang mereka lakukan. Kekurangan penilaian kinerja tersebut menyulitkan pihak manajeman dalam melihat kinerja karyawan karena penilaiannya subjektif dan tidak adanya tolak ukur untuk melihat pencapaian kinerja.

Penilaian kinerja yang obyektif merupakan indikator prestasi kerja yang dapat diperiksa oleh orang lain dan biasanya bersifat kuantitatif (Wibowo, 2008). Kriteria untuk mengukur standar kinerja secara kuantitatif merupakan ukuran paling mudah untuk disusun dan diukurnya, yaitu hanya dengan menghitung seberapa banyak unit keluaran kinerja harus dicapai dalam kurun waktu tertentu (Wirawan, 2009).

Dalam upaya mengukur kinerja yang sangat kompleks, perlu bagi penilai untuk menentukan indikator kinerja yang tepat dan baik. Oleh karena itu, adanya key performance indicator atau indikator kinerja utama merupakan jawaban atas keinginan karyawan yang selalu menginginkan ukuran yang lebih objektif dalam penilaian hasil pekerjaannya (Moeheriono, 2012). Berdasarkan penelitian yang dilakukan oleh Izzhati (2011); Agusman, Laricha, \& Metasilani (2013); Harnanda, Hidayat, \& Putri (2013); serta Junep (2013) dapat disimpulkan bahwa penyusunan KPI oleh karyawan dapat digunakan untuk merepresentasikan pencapaian kinerja SDM, mengetahui dan menganalisis hasil pengukuran kinerja SDM.

Rivai dan Sagala (2013) mengatakan bahwa penilaian kinerja digunakan perusahaan untuk menilai kinerja karyawannya atau mengevaluasi hasil pekerjaan karyawan. Timpe (2002) menambahkan bahwa penilaian harus mengenali prestasi serta membuat rencana untuk meningkatkan kinerja karyawan. Sasaran penilaian adalah untuk membuat pandangan tentang diri mereka sendiri seperti apa adanya. Orang yang dinilai harus mengenali kebutuhan untuk memperbaiki kinerja kerja dan memberikan komitmen terhadap suatu rencana perbaikan kinerja kerja. Harus ada kesepakatan bersama tentang rencana pengembangan untuk masa penilaian mendatang. Penilaian kinerja yang disusun juga harus dapat diterima oleh semua karyawan di dalam perusahaan. Dalam hal ini, untuk mewujudkan penilaian kinerja yang dapat diterima maka dibutuhkan adanya partisipasi karyawan dalam penyusunannya.

Lawler dan Hackman (1969) mengatakan bahwa ketika individu-individu berpartisipasi dalam prosedur penetapan sasaran kelompok, produktivitas akan meningkat secara menggembirakan. Proses penerapan sasaran yang efektif perlu melibatkan seluruh anggota organisasi sehingga sasaran yang ditetapkan dimengerti, disepakati, dan dapat dikontrol secara bersama-sama.

Moorhead dan Griffin (2013) mengatakan bahwa karyawan yang berpartisipasi dalam pengambilan keputusan mungkin lebih berkomitmen melaksanakan keputusan dengan baik. Selanjutnya, sukses dalam mengambil keputusan, melaksanakannya, dan kemudian melihat akibat positif dapat membantu memuaskan kebutuhan karyawan akan pencapaian, memberikan pengakuan dan tanggung jawab, dan meningkatkan harga diri. Keterlibatan karyawan dalam pekerjaan mereka juga memainkan peran penting dalam motivasi. Motivasi merupakan keadaan dalam pribadi seseorang yang mendorong individu untuk melakukan kegiatan 
tertentu (Tranggono \& Kartika, 2008). Kegiatan tertentu dalam penelitian ini merupakan kegiatan untuk mencapai sasaran kerja.

Sasaran kerja dalam penelitian ini merupakan sasaran kerja yang harus dicapai oleh setiap karyawan dalam upaya melaksanakan pekerjaan yang diberikan pada mereka. Pada proses penetapan sasaran kerja ini dilakukan melalui partisipasi bawahan dan atasan yang kemudian dapat menyepakati sasaran kerja yang sudah disusun. Li dan Butler (2004) menemukan bahwa penginformasian alasan dan dasar pemikiran suatu tujuan serta partisipasi saat penentuan tujuan sebagai faktor penting untuk meningkatkan komitmen seseorang pada sasaran tersebut. Partisipasi adalah suatu situasi yang diusahakan dalam rangka memberikan kesempatan saling berbagi pendapat maupun pemikiran perihal kinerja organisasi, melibatkan individu atau kelompok yang lebih tinggi maupun yang lebih rendah posisinya dalam suatu organisasi (Glew, O'Leary-Kelly, Griffin \& Van Fleet, 1995). Individu bersamasama mengambil bagian dalam suatu kelompok kerja.

Manfaat partisipasi adalah memfasilitasi karyawan berkumpul, bertukar dan berbagi informasi relevan mengenai pekerjaan partisipasi juga mendorong terjadinya komunikasi internal. Disamping itu karyawan dapat mengembangkan rencana efektif sehingga membantu pencapaian sasaran (Hoegl \& Parboteeah, 2006). Emmanuel, Kominis dan Slapnicar (2008) menyatakan partisipasi memberikan peluang terjadinya negosiasi diantara pihak yang terlibat. Partisipasi membuat orangorang yang terlibat mempersepsi bahwa target telah spesifik dan tujuan realistis untuk dicapai. Rigkasnya, pastisipasi memiliki dampak langsung dan tidak langsung terhadap peningkatan komitmen pencapaian sasaran.
Pada penelitian ini komitmen pencapaian sasaran kerja dirumuskan sebagai sikap yang menunjukkan seberapa kuat ikatan individu untuk terlibat dalam pencapain sasaran kerjanya demi mencapai tujuan organisasi. Untuk dapat meningkatkan komitmen pencapaian sasaran kerja dibutuhkan partisipasi dari karyawan untuk dapat menyusun KPI pada jabatan masingmasing yang nantinya dapat digunakan sebagai acuan karyawan dalam mencapai sasaran kerjanya serta dapat digunakan untuk mengukur seberapa besar pencapain sasaran kerja yang sudah berhasil diselesaikan oleh karyawan.

Dalam teori model dari Lewin (dalam Cummings \& Worley, 2005) menjelaskan bahwa untuk mengubah perilaku karyawan diperlukan terlebih dahulu pengenalan dan pengetahuan akan perilaku yang akan dibentuk agar para karyawan mau dan dapat mengubah perilaku mereka sesuai dengan yang diharapkan perusahaan. Berdasarkan teori dari Lewin tersebut dapat dipahami bahwa dalam membentuk komitmen pencapaian sasaran kerja haruslah memberi informasi dan pengetahuan kepada karyawan bagaimana menyusun KPI yang nantianya dapat mereka gunakan sebagai acuan untuk mencapai sasaran kerja mereka yang lebih jelasnya dapat dilihat pada gambar 1 .

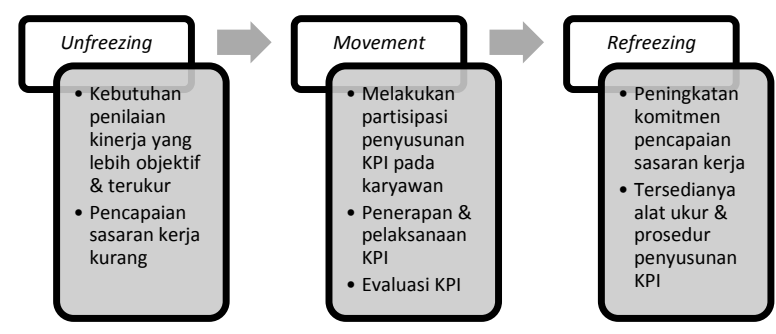

Gambar 1.

Pengaruh Partisipasi Penyusunan KPI terhadap Komitmen Pencapaian Sasaran Kerja

PT. XYZ menyadari bahwa mereka membutuhkan alat ukur yang dapat menilai pencapaian sasaran kerja dari para 
karyawannya yang lebih objektif dan terukur karena pencapain sasaran kerja karyawan masih kurang tercapai. Untuk mengatasi hal tersebut dilakukanlah penyusun KPI yang akan dilakukan atas dasar partisipasi antara atasan dan bawahan (pemegang jabatan).

Dengan adanya partisipasi dalam penyusunan KPI dan dapat diterima serta dirasakan sebagai milik oleh semua pihak di dalam jajaran organisasi akan cenderung berhasil dalam pelaksanaannya (Moeheriono, 2012). Hal ini didukung dengan penelitian yang dilakukan oleh Sholihin, Richard, Mangena, dan Li (2011) menemukan bahwa partisipasi dalam penetapan sasaran memiliki hubungan positif dengan komitmen sasaran. Klein, dkk (2001) memaknai komitmen sasaran sebagai penilaian positif terhadap tujuan dan target-target yang ditetapkan serta memiliki kepedulian tinggi untuk melaksanakannya.

Hal ini sesuai dengan yang akan dilakukan dalam penelitian ini, bahwa penilaian kinerja KPI yang akan disusun berdasarkan partisipasi karyawan serta adanya saling menyepakati antara atasan dan bawahan dalam KPI yang disusun. Moeheriono (2012) mengatakan bahwa KPI dapat dirumuskan secara top-down, dan diukur berdasarkan data yang riil guna melihat kinerja pegawai yang sesungguhnya. Selain itu, Timpe (2002) juga menambahkan bahwa karyawan berada dalam posisi yang jauh lebih baik untuk menentukan kemajuan individu kearah tingkat kinerja yang lebih tinggi bila karyawan terlibat dalam penulisan standar kinerja untuk kinerja kerja yang akan datang serta menggunakan ukuran-ukuran yang telah saling disepakati dengan penilai.

Pada partisipasi penyusunan KPI ini karyawan diberikan pengetahuan mengenai konsep penilaian kinerja KPI dan langkahlangkah dalam penyusunannya. Karyawan diberikan pemahaman bahwa partisipasi dalam penyusunan KPI ini dapat memberikan penilaian yang lebih objektif sebagai penilaian sasaran kerja. Partisipasi karyawan juga dapat memberikan kejelasan pada mereka tentang target kerja mereka dan menumbuhkan rasa tanggung jawab dalam menjalankannya. Selain itu juga, diharapkan setelah adanya kesepakatan dalam penyusunan KPI antara atasan dan pemegang jabatan, serta dilaksanakan dan diterapkan dalam pekerjaan.

Berdasarkan hasil dari penelitian yang dilakukan oleh beberapa peneliti sebelumnya, seperti Hollenbeck, Williams, dan Klein (1989); Nugraheni (2009); Sholihin, Pike, Mangena, dan Li (2011); serta Hidayatullah (2012) dengan hasil penelitian yang berbeda-beda tentang komitmen sasaran seperti yang sudah dijelaskan di atas. Peneliti tertarik untuk melakukan penelitian kembali dalam hal ini komitmen lebih dispesifikkan lagi, yaitu komitmen pencapaian sasaran kerja, dengan pemberian perlakuan partisipasi penyusunan key performance indicator (KPI). Dalam hal ini KPI merupakan penilaian sasaran kerja yang dapat melihat pencapaian sasaran kerja dari karyawan. KPI yang akan disusun adalah KPI individu, serta mengembangkan tiga aitem dari hasil penelitian Hollenbeck, Williams, dan Klein yang digunakan untuk mengukur komitmen pencapaian sasaran kerja. Hipotesis pada penelitian ini, yaitu ada pengaruh partisipasi penyusunan Key Performance Indicator (KPI) terhadap komitmen pencapaian sasaran kerja pada karyawan di PT. XYZ.

\section{METODE}

Penelitian ini melibatkan dua variabel, yaitu komitmen pencapain sasaran kerja 
(sebagai variabel dependent) dan partisipasi penusunan key performance indicator (KPI) (sebagai variabel independen). Komitmen pencapaian sasaran adalah sikap yang menunjukkan seberapa kuat ikatan individu untuk terlibat dalam pencapaian sasaran kerjanya demi mencapai tujuan organisasi. Tinggi dan rendahnya komitmen pencapaian sasaran kerja individu dapat dilihat dari skor yang didapat dari Skala Komitmen Pencapaian Sasaran kerja, yang disusun berdasarkan hasil penelitian Hollenbeck, William, dan Klein (1989) berdasarkan pada ciri-ciri perilaku, yaitu sasaran kinerja merupakan tujuan yang harus dicapai, kesediaan untuk melakukan banyak usaha dalam mencapai sasaran kerja, dan adanya keterikatan untuk mencapai sasaran kinerja. Skala ini terdiri dari 14 aitem dengan koefisien reliabilitas sebesar 0,841. Skala ini diterjemahkan dalam aitem-aitem pernyataan dengan pola Likert. Respon tersebut diungkap dalam lima kategori, yaitu sangat setuju (SS), setuju (S), netral $(\mathrm{N})$, tidak setuju (TS) dan sangat tidak setuju (STS). Aitem-aitem skala komitmen pencapaian sasaran kerja dibagi menjadi dua jenis, yaitu favorable dan unfavorable. Pada aitem-aitem favorable, skor bergerak dari 5 sampai 1 dengan kategori, yaitu sangat setuju $(\mathrm{SS})=5$, setuju $(\mathrm{S})=4$, netral $(\mathrm{N})=3$, tidak setuju $(\mathrm{TS})=2$ dan sangat tidak setuju (STS) $=1$. Sebaliknya untuk aitem-aitem unfavorable pemberian skornya merupakan kebalikan skor pada aitem-aitem favorable. Contoh aitemnya, "saya berusaha lebih giat untuk menyelesaikan pekerjaan".

Partisipasi penyusunan Key Performance Indicator (KPI) adalah keterlibatan langsung karyawan dalam merancang dan menyusun KPI sebagai sistem penilaian kinerja. Proses penyusunan KPI dilakukan melalui enam tahap: (1) sosialisasi penyusunan KPI; (2) simulasi KPI; (3) melakukan penyusunan KPI yang dilakukan oleh masing-masing jabatan untuk menetapkan tugasnya, indikator keberhasilan serta target; (4) diskusi antara pemegang jabatan dengan atasan mengenai KPI yang sudah disusun dan menentukan bobot dari setiap tugas; (5) melakukan penerapan KPI yang telah disusun oleh masing-masing pemegang jabatan; dan (6) melakukan evaluasi KPI yang dilakukan oleh atasan.

Subjek dalam penelitian ada 36 subjek, yang terbagi dalam kelompok eksperimen dan kelompok kontrol, dengan masingmasing terdiri atas 18 subjek, yang teknik random assignment. Peneliti memasukkan secara acak subjek penelitian ke dalam kelompok penelitian dengan terlebih dahulu diberikan skala komitmen pencapaian sasaran kerja. Jika subjek mendapatkan skor dari hasil skala di bawah tinggi $(x<58,35)$ maka akan menjadi subjek penelitian. Karakteristik para subjek penelitian, yaitu seluruh karyawan PT. XYZ yang berada pada posisi jabatan sebagai kepala divisi, kepala subdivisi, dan kepala seksi.

Penelitian ini merupakan penelitian eksperimen dengan menggunakan desain penelitian pretest posttest control group design. Pada penelitian ini kelompok eksperimen mendapatkan perlakuan partisipasi penyusunan KPI, sedangkan kelompok kontrol tidak mendapatkan perlakuan.

Prosedur penelitiannya melalui beberapa tahap: (1) tahap persiapan dengan melakukan penyusunan skala komitmen pancapaian sasaran kerja, penyusunan modul KPI, pemilihan pemateri, dan pengurusan surat izin; (2) tahap pelaksanaan penelitian yang meliputi pengambilan data pretest, sosialisasi KPI, simulasi KPI, penyusunan KPI, pelaksanaan dan penerapan KPI selama 3 minggu, evaluasi KPI, serta pengambilan 
data posttest. Total waktu yang dibutuhkan untuk melakukan perlakuan, yaitu selama 32 hari (mulai dari sosialisasi sampai dengan evaluasi KPI). Analisis data dilakukan dengan teknik anova dengan bantuan program SPSS 21 for Windows.

\section{HASIL DAN PEMBAHASAN}

Berdasarkan dari analisis data yang sudah dilakukan diperoleh nilai $\mathrm{F}=0,43(p>$ 0,05), artinya tidak ada pengaruh partisipasi penyusunan KPI terhadap komitmen pencapaian sasaran kerja. Hasil penelitian ini menunjukkan bahwa hipotesis dalam penelitian ini yang menyatakan bahwa ada pengaruh partisipasi penyusunan KPI terhadap komitmen pencapain sasaran kerja ditolak. Data pretest pada kelompok eksperimen dengan memperoleh mean sebesar 52,38 dan posttest memperoleh mean sebesar 52,94. Pada kelompok kontrol saat pretest memperoleh mean sebesar 52,88 dan posttest dengan memperoleh mean sebesar 52,27. Dalam hal ini dilihat bahwa ada perbedaan pada kelompok eksperimen antara mean yang diperoleh pada saat pretest dan posttest walaupun perbedaannya kecil.

Dalam penelitian ini juga dilakukan evaluasi terhadap kelompok eksperimen pada saat sosialisasi penyusunan KPI dan evaluasi setelah selesai pelaksanaan KPI dengan hasil sebagai berikut:

\section{Evaluasi reaksi}

Evaluasi reaksi diberikan setelah sosialisasi penyusunan KPI dengan memberikan 7 pernyataan yang diberikan pada subjek penelitian untuk mengetahui tanggapan subjek yang berada di kelompok eksperimen terhadap partisipasi mereka mengikuti sosialisasi penyusunan KPI. Berdasarkan hasil evaluasi reaksi diketahui $81,7 \%$ memilih jawaban pernyataan setuju dan sebesar $18,3 \%$ memilih jawaban sangat setuju sedangkan yang memilih jawaban pernyataan tidak setuju dan sangat tidak setuju tidak ada yang memilih. Pernyataan pada evaluasi reaksi, mencakup seperti pemateri mampu menjelaskan serta menyajikan materi secara jelas dan sistematis pada peserta. Hasil dari evaluasi reaksi selutuh subjek menunjukkan tingkat kepuasan seluruh subjek penelitian terhadap sosialisasi penyusunan KPI yang telah diikuti, terutama mengenai pemateri, metode, alat bantu/ media pembelajaran, materi, dan fasilitas pendukung.

\section{Evaluasi learning}

Evaluasi learning diberikan pada saat sebelum dan sesudah pemberian materi penyusunan KPI, yang terdiri masingmasing 6 pertanyaan untuk mengetahui peningkatan pengetahuan subjek penelitian yang berada di kelompok eksperimen. Berdasarakan hasil evaluasi diketahui bahwa terjadi peningkatan pengetahuan para subjek penelitian sebelum dan sesudah pemberian materi penyusunan KPI. Hal tersebut dapat dilihat pada hasil pretest subjek yang memiliki kategori skor rendah ada sebesar $5,60 \%$, kategori sedang sebesar 66,70\%, dan kategori tinggi sebesar $27,70 \%$. Pada saat posttest evaluasi learning mengalami perubahan pada subjek yang memiliki kategori skor sedang ada sebesar 5,60\%, kategori tinggi sebesar $94,40 \%$, dan skor pada kategori rendah tidak ada. Hasil evaluasi learning menunjukkan adanya peningkatan skor subjek pada saat pretest dan posttest, seperti yang ditampilkan pada tabel 1 .

Tabel 1.

Deskripsi Skor Pretest dan Posttest

\begin{tabular}{cccc}
\hline No & Kategori Skor & Pretest & Posttest \\
\hline 1 & Rendah & $5,6 \%$ & $0 \%$ \\
2 & Sedang & $66,7 \%$ & $5,6 \%$ \\
3 & Tinggi & $27,7 \%$ & $94,4 \%$ \\
\hline
\end{tabular}

\section{Evaluasi KPI}

Evaluasi KPI dilakukan setelah subjek selesai melaksanakan dan menerapkan KPI 
yang sudah disusun sebelumnya, dan pelaksanaannya selama 3 minggu. Berdasarkan hasil evaluasinya adalah diketahui ada 3 subjek yang memiliki skor KPI dalam kategorisasi sangat baik, ada 4 subjek yang memiliki skor KPI dalam kategorisasi baik, ada 5 subjek yang memiliki skor KPI dalam kategorisasi sedang, ada 5 subjek yang memiliki skor KPI dalam kategorisasi kurang memuaskan, dan ada 1 subjek yang memiliki skor KPI dalam kategorisasi tidak memuaskan. Hal-hal yang menyebabkan subjek mendapatkan skor kurang memuaskan dan tidak memuaskan karena disebabkan target kerja mereka yang pelaksanaannya bulanan dan tahunan sehingga dilihat dalam waktu 3 minggu kurang terlihat hasil kerjanya, serta mereka juga kurang melakukan pencatatan baik pada tugas yang sudah dilaksanankan dan yang belum dilaksanakan. Pada saat evaluasi juga terjadi perubahan tugas, dan target kerja pada 5 posisi jabatan. Perubahan bobot setelah pelaksanaan KPI ada 2 posisi jabatan dan ada sebanyak 13 jabatan yang tidak mengalami perubahan tugas dan target kerja setelah pelaksanaan KPI, serta ada 16 jabatan yang tidak mengalami perubahan bobot setelah pelaksanaan KPI.

Berdasarkan hasil analisis dengan melakukan perhitungan uji $\mathrm{F}$ dengan hasil $\mathrm{F}=0,425(p>0,05)$, maka hipotesis dalam penelitian ini ditolak, artinya tidak ada pengaruh partisipasi penyusunan KPI terhadap komitmen pencapaian sasaran kerja secara signifikan. Hal ini menunjukkan bahwa perlakuan partisipasi penyusunan KPI yang diberikan pada karyawan tidak dapat mempengaruhi peningkatan komitmen pancapaian sasaran kerja.

Berbeda dengan yang dikatakan oleh Moeheriono (2012) bahwa dengan adanya partisipasi dalam penyusunan KPI dan dapat diterima serta dirasakan sebagai milik oleh semua pihak di dalam jajaran organisasi akan cenderung berhasil pelaksanaannya. Ditambahkan oleh Moorhead dan Griffin (2013) yang menyatakan bahwa karyawan yang berpartisipasi dalam pengambilan keputusan mungkin lebih berkomitmen untuk melaksanakan keputusan dengan baik. Selain itu, Timpe (2002) juga menambahkan bahwa karyawan berada dalam posisi yang jauh lebih baik untuk menentukan kemajuan individu kearah tingkat kinerja yang lebih tinggi bila karyawan terlibat dalam penulisan standar kinerja untuk pekerjaannya yang akan datang serta menggunakan ukuran-ukuran yang telah saling disepakati dengan penilai.

Pada penelitian ini walaupun penyusunan KPI sudah dilakukan berdasarkan partisipasi para karyawan dan kesepakatan antara para karyawan dengan atasan mereka, namun kurang dapat meningkatkan komitmen mereka dalam mencapai sasaran kerja dikarenakan evaluasi yang diberikan pada saat perlakuan tidak sampai pada tahap evaluasi result dan evaluasi KPI yang disampaikan atasan pada para subjek atas hasil penilaian KPI yang sudah dijalankan, penyampaian penilaiannya masih belum sesuai dengan tahapan penyampaian evaluasi penilaian. Disamping itu, ada kejadian yang terjadi yang dialami oleh para subjek setelah perlakuan baik itu kendala yang dialami dalam pekerjaan ataupun di luar pekerjaan. Selain itu, skala yang digunakan pada saat pretest dan posttest masih dapat diingat oleh para subjek sehingga mereka dapat menduga penelitian yang sedang dilakukan ataupun perlakuan yang sudah diberikan sehingga mengurangi hubungan sebab akibat antara variabel penelitian ini.

Fibrianti dan Riharjo (2013) mengatakan bahwa komitmen menunjukkan keyakinan 
dan dukungan yang kuat terhadap nilai dan sasaran (goal) yang ingin dicapai oleh organisasi, bagi individu yang berkomitmen tinggi, pencapaian tujuan organisasi merupakan hal yang penting yang harus dicapai serta berpandangan yang positif dan berbuat yang terbaik untuk kepentingan organisasi. Kreitner dan Kinicki (2003) menyatakan bahwa komitmen terhadap sasaran merupakan lingkup di mana seorang individu secara pribadi terikat pada pancapaian suatu sasaran. Klein, dkk (2001) menyatakan bahwa defenisi komitmen sasaran menunjukkan dorongan untuk mengerahkan usaha dalam mencapai sasaran, berusaha mencapai sasaran secara terusmenerus, dan tidak ada keinginan menurunkan atau menunda pencapaian sasaran.

Pada penelitian ini juga dilakukan beberapa evaluasi, seperti evaluasi reaksi, evaluasi learning dan evaluasi KPI yang sudah dilakukan. Pada evaluasi reaksi dapat diketahui bahwa tingkat kepuasan subjek penelitian terhadap sosialisasi penyusunan KPI yang telah diikuti, terutama mengenai pemateri, metode, alat bantu/ media pembelajaran, materi, dan fasilitas pendukung. Pada evaluasi learning diketahui bahwa terjadi peningkatan pengetahuan para subjek penelitian sebelum dan setelah pemberian materi penyusunan KPI. Hal tersebut dapat terlihat pada hasil pretest-posttest evaluasi learning yang mengalami peningkatan skor yang diperoleh oleh para subjek penelitian.

Menurut Kirkpatrik (dalam Sopacua dan Budijanto, 2007); Kristantia dan Trisunarno (2012); Manan, Nor, dan Omar (2013) mengatakan bahwa evaluasi terhadap efektivitas program pelatihan yang mencakup empat level evaluasi, yaitu level 1 reaction, level 2 learning, level 3 behavior, dan level 4 result. Pada penelitian ini evaluasi partisipasi penyusunan KPI hanya samapi pada evaluasi level 2 learning. Dalam penelitian ini tidak sampai pada evaluasi level 3 behavior, dan level 4 result, sehingga tidak terlihat terjadinya perubahan komitmen pencapaian sasaran kerja seperti yang diharapkan dari hasil pemberian perlakuan partisipasi penyusunan KPI. Dalam penelitian ini berdasarkan evaluasi yang sudah dilakukan dapat diketahui bahwa partisipasi penyusunan KPI lebih cenderung meningkatkan pengetahuan dan pemahaman subjek mengenai cara pencapaian sasaran kerja, hal ini sama dengan hasil penelitian yang dilakukan oleh Hidayatullah (2012). Selain itu, Verawati dan Utomo (2011) juga menambahkan bahwa dengan partisipasi yang aktif diharapkan pekerja dapat meningkatkan kinerjanya yang tentunya hal ini akan tergantung pada sikap, perilaku, dan tindakan karyawan yang bersangkutan saat mereka bekerja.

Disamping itu juga, ada kejadian yang terjadi setelah dilakukannya pretest, yaitu dilakukannya sosialisasi penyusunan KPI, simulasi KPI, penyusunan KPI, dan evaluasi sampai akhirnya dilakukan pengambilan data posttest pada saat itu peneliti tidak dapat mengontrol hal-hal yang terjadi dan dialami oleh subjek penelitian. Walaupun pada saat pemberian sosialisasi peneliti sudah melakukan pemilihan tempat dan melengkapi fasilitas yang dibutuhkan oleh subjek penelitian, pada saat simulasi peneliti juga memfasilitasi subjek penelitian dengan memberikan mereka latihan untuk penyusunan KPI, dan melakukan latihan untuk cara perhitungan skor KPI. Dalam hal ini, peneliti memfasilitasi subjek dan atasan untuk melakukan kesepakatan pada penyusunan KPI yang sudah disusun akan tetapi peneliti tidak dapat melakukan pengontrolan pada sikap, perilaku, dan tindakan subjek yang bersangkutan saat mereka bekerja. Pada tahap evaluasi KPI, 
peneliti juga memfasilitasi subjek dan atasan untuk melakukan evaluasi pada pelaksanaan KPI yang sudah dilakukan oleh pemegang jabatan. Pada tahap evaluasi KPI juga peneliti sudah melakukan pertemuan dengan team penilai yang akan melakukan evaluasi untuk sosialisasi dan simulasi penyusunan KPI dan cara untuk penyampaian evaluasi, namun pada saat evaluasi juga peneliti tidak dapat melakukan pengontrolan pada evaluasi yang disampaikan atasan pada bawahan tentang kinerja bawahannya.

Sheal (2003) menambahkan bahwa dalam hal penilaian kinerja pada tahap evaluasi kinerja itu saat memegang peranan penting karena atasan harus dapat merangkum apa yang sudah dibahas dan disepakati pada tugas bawahan serta melakukan tambahan pujian untuk pekerjaan yang bagus, selain itu atasan juga sebaiknya menunjukkan antusiasme serta kepercayaan pada rencana-rencana tugas yang sudah disepakati dan mengakhiri sesi evaluasi dengan nada positif.

Kejadian yang terjadi sebelum posttest dilakukan hal itu merupakan salah satu ancaman pada validitas internal, yaitu history yang salah satunya dapat mempengaruhi validitas internal yang dapat mempengaruhi kekuatan hubungan sebab-akibat antara variabel partisipasi penyusunan KPI dengan variabel komitmen pencapaian sasaran kerja, seperti yang dikatakan oleh Shadish, Cook, dan Campbell (2002). Selain ancaman history, ada ancaman lain yang mempengaruhi, yaitu testing. Pada saat penelitian peneliti memberikan pretestposttest skala komitmen pencapaian sasaran kerja kepada subjek untuk melihat perbedaan sebelum dan sesudah pemberian perlakukan partisipasi penyusunan KPI. Dalam hal ini, skala yang diberikan sama isinya pada saat pretest-posttest hanya yang membedakan adalah nomor urut pernyataan yang sudah diacak, dan cover skala yang dibedakan. Ternyata walaupun sudah dilakukan pengontrolan akan tetapi subjek berusaha untuk mengingat soal, subjek juga dapat menduga masalah yang sedang diteliti ataupun perlakukan yang akan diberikan, dan kondisi ini menyebabkan hasil pengukuran tidak akurat karena tidak sesuai dengan keadaan subjek sebenarnya, sehingga menurunkan hubungan sebab akibat yang dihasilkan.

Berdasarkan penelitian yang sudah dilakukan dapat direkomendasikan beberapa saran, yaitu:

1. Pihak manajemen perusahaan diharapkan agar lebih meningkatkan monitoring dan controlling terhadap kinerja karyawan dengan melakukan evaluasi kerja sehingga dapat meningkatkan komitmen karyawan dalam mencapai sasaran kerja, dan dapat mengetahui kemajuan kinerja dari masing-masing karyawan.

2. Karyawan disarankan untuk lebih meningkatkan komitmen pencapaian sasaran kerja sehingga target kerja yang sudah diberikan dapat tercapai.

3. Peneliti selanjutnya disarankan untuk melakukan pengontrolan pada faktorfaktor yang dapat mempengaruhi validitas internal, seperti ancaman history dan testing yang dapat mempengaruhi hubungan sebab-akibat antara variabel partisipasi penyusunan KPI dan variabel komitmen pencapaian sasaran kerja.

\section{KESIMPULAN}

Berdasarkan hasil penelitian yang sudah dilakukan, dapat ditarik kesimpulan bahwa tidak ada pengaruh yang signifikan dari partisipasi penyusunan KPI terhadap peningkatan komitmen pencapaian sasaran kerja $(\mathrm{F}=0,43 ; p>0,05)$. Partisipasi karyawan dalam penyusunan KPI lebih cederung meningkatkan pengetahuan dan 
pemahaman subjek mengenai cara pencapaian sasaran kerja yang dilihat dari hasil evaluasi reaksi, dan evaluasi learning.

\section{DAFTAR PUSTAKA}

Agusman, D., Laricha, L., \& Metasilani. (2013). Manajeman sistem kerja untuk peningkatan kinerja karyawan PT. CP. Jurnal Ilmiah Teknik Industri, 1 , 103108.

Armstrong, M. (2003). Mengelola karyawan: Buku wajib bagi manajer lini. Terjemahan oleh Ramelan dan Dwi Prabaningtyas. Jakarta: PT Gramedia.

Cumming, T. G, dan Worley, C. G. (2005). Organization development and change (8th edition). Mason, USA: Thomson Corporation.

Emmanuel, C. R., Kominis, G., \& Slapnicar, S. (2008). The impact of target setting on manajerial motivation \& performance. Target setting \& Managerial Motivation, AAA, 1-28. http://dx.doi.org/10.2139/ssrn.100417 9

Fibrianti, D., \& Riharjo, I. B. (2013). Pengaruh partisipasi anggaran, desentralisasi, komitmen organisasi, dan ketidakpastian lingkungan terhadap kinerja manajerial pada pemerintahan kota surabaya. Jurnal Ilmu dan Riset Akuntansi, 1 , 108-121.

Glew, D. J., O’Leary-Kelly, A. M., Griffin, R. W., \& Van Fleet, D. D. (1995). Participation in organizations: A preview of the issue and proposed framework for future analysis. Journal of Management, 21 , 395-421. DOI: $10.1177 / 014920639502100302$
Harnanda, S. L., Hidayat, A., \& Putri, S. A. (2013). Analisis pengukuran kinerja sumber daya manusia menggunakan metode human resources scorecard (Studi kasus di PT. Erindo Mandiri, Pasuruan). Jurnal. [Online] Didapatkan di http://skripsitip.staff.ub.ac.id/files/201 3/08/Jurnal-Silma-L.H.pdf (Akses: 8 November 2014).

Hidayat, M. (2010). Analisis komitmen (affective, continuance dan normative) terhadap kualitas pelayanan pengesahan STNK kendaraan bermotor (studi empiris pada kantor bersama samsat di proponsi kalimantan timur). Jurnal Manajemen dan Kewirausahaan, 12, 11-23.

Hidayat, R. (2013). Pengaruh kepemimpinan terhadap komunikasi, kepuasan kerja, dan komitmen organisasi pada industri perbankan. Makara Seri Sosial Humaniora, 17, 19-32,

Hidayatullah, M. S. (2012). Pengaruh partisipasi perencanaan strategis berbasis balanced scorecard terhadap peningkatan komitmen tujuan (Tesis). Universitas Gadjah Mada, Yogyakarta.

Hoegl, M., \& Parboteeah, K. P. (2006). Team goal commitment in innovative projects. International Journal of Innovation Management, 10, 299324. DOI: 10.1142/ S1363919606001 $51 \mathrm{X}$

Hollenbeck, J. R., Williams, C. R., \& Klein, H. J. (1989). An Empirical examination of the antecedents of commitment to difficult goals. Journal of Applied Psychology, 74, 
18-23. $\quad$ http://dx.doi.org/10.1142 /S136391960600151X

Izzhati, D. N. (2011). Analisis kinerja sumber daya manusia dengan pendekatan human resources score card. Jurnal Dian, 11, 209-214.

Junep, K. N. (2013). Pengaruh penyusunan key performance indicators (KPI) terhadap persepsi keadilan prosedural penilaian kinerja karyawan di PT. X Tesis tidak dipublikasikan. Yogyakarta : Universitas Islam Indonesia.

Klein, H. J., Wesson, M. J., Hollenbeck, J. R., \& Alge, B. J. (1999). Goal commitment and the goal-setting process: Conceptual clarification and empirical synthesis. Journal of Applied Psychology, 84, 885-896. http://dx.doi.org/10.1037/00219010.84.6.885

Klein, H. J., Wesson, M. J., Hollenbeck, J. R., Wright, P. M., \& DeShon, R. P. (2001). The assesment of goal commitment: A measurement model meta-analysis.

Organizational Behavior and Human Decision Process, 85, 32-55. Doi:10.1006/obhd.2000.293

Kreitner, R. \& Kinicki, A. (2003). Perilaku organisasi. Jakarta: Salemba Empat

Kristantia, P. \& Trisunarno, L. (2012). Evaluasi pelatihan untuk operatot dengan menggunakan metode return on investment di PT. H.M. Sampoerna tbk. Jurnal Teknik Pomits, 1, 1-5.

Lau, WK. (2012). The impacts of personality traits and goal commitment on employees' job satisfaction. Business and Economics Journal, BEJ-59.
Lawler, E.E., \& Hackman, J.R. (1969). Impact of employee participation in the development of pay incentive plans: A field experiment. Journal of Applied Psychology, 53, 457-471. http://dx.doi.org/10.1037/h0028657

Li, A., \& Butler, A. B. (2004). The effect of participation in goal setting and goal rationales on goal commitment: An exploration of justice mediators. Journal of Bussiness and Psychology, 19, 37-51. http://dx.doi.org/10.1023 /B:JOBU.0000040271.74443.22

Locke, E.A., Shaw, K.N., Saari, L.M., \& Latham, G.P. (1981). Goal setting and task performance: 1961-1980. Psychological Bulletin, 90, 125-152.

Manan, K. A., Nor, S. Md., \& Omar, B. (2013). Model penilaian Kirkpatrick: Mengakaji pengaruh komunikasi terhadap keberkesanan latihan. Jurnal Komunikasi, 29, 31-50.

Moeheriono. (2012). Perencanaan, aplikasi dan pengembangan indikator kinerja utama (IKU) bisnis dan publik (cetakan kedua). Jakarta: Rajawali Pers.

Moorhead, G \& Griffin, R. W. (2013). Perilaku organisasi manajemen sumber daya manusia dan organisasi (edisi sembilan). Penerjemah Diana Angelica. Jakarta: Salemba Empat.

Nugraheni, R. (2009). Pengaruh media kominikasi yang berbeda dalam meningkatkan komitmen tujuan. Tesis tidak dipublikasikan. Yogyakarta : Universitas Gadjah Mada.

Oktorita, Y. B., Rosyid, H. F., \& Lestari, A. (2001). Hubungan antara sikap terhadap penerapan program $\mathrm{K} 3$ 
dengan komitmen karyawan pada perusahaan. Jurnal Psikologi, 2, 116132.

Rivai, V \& Sagala, E. J. (2013). Manajemen sumber daya manusia untuk perusahaan (cetakan kelima). Depok: PT Rajagrafindo Persada.

Shadish, W. R., Cook, T. D., \& Campbell, D. T. (2002). Experimental and quasiexperimental designs for generalized causal inference. Boston, USA: Houghton Mifflin Company.

Sheal, P. (2003). Pengembangan staff. Penerjemah. Oleh Bern. Hidayat. Jakarta, PT. Gramedia.

Sholihin, M., Richard, P., Mangena, M., \& Li, J. (2011). Goal-setting particepation and goal commitment: Examining the mediating roles of procedural fairness and interpersonal trust in a UK financial services organisation. The British Accounting Review, 43, 135-146.

Sopacua, E. \& Budijanto, D. (2007). Evaluasi 4 tahap dari kirkpatrik sebagai alat dalam evaluasi pasca pelatihan. Buletin Penelitian Sistem Kesehatan, 10, 371-379.
Timpe, A. D. (2002). Seri Manajemen Sumber Daya Manusia. Penerjemah Sofyan Cikmat. Jakarta: PT. Gramedia.

Tranggono, R. P., \& Kartika, A. (2008). Pengaruh komitmen organisasi profesional terhadap kepuasan kerja auditor dengan motivasi sebagai variabel intervening (Studi empiris terhadap kantor akuntan publik di semarang). Jurnal Bisnis dan Ekonomi, 15, 80-90.

Verawati, Y., \& Utomo, J. (2011). Pengaruh komitmen organisasi, partisipasi dan motivasi terhadap kinerja karyawan pada PT. Bank Lippo Tbk cabang kudus. Analisis Manajemen, 5, 1-8.

Wibowo. (2008). Manajemen kinerja. Jakarta: PT Raja Grafindo Persada.

Wirawan. (2009). Evaluasi kinerja sumber daya manusia: Teori, aplikasi, dan penelitian. Jakarta: Salemba Empat.

Yudhaningsih, R. (2011). Peningkatan efektivitas kerja melalui komitmen, perubahan, dan budaya organisasi. Jurnal Pengembangan Humaniora, $11,40-51$ 